Guest Editorial, part of a Special Feature on Navigating Trade-offs: Working for Conservation and Development Outcomes

\title{
Navigating Trade-Offs: Working for Conservation and Development Outcomes
}

\author{
$\underline{\text { Bruce M. Campbell }}^{1}, \underline{\text { Jeffrey A. Sayer }}^{2}$, and Brian Walker ${ }^{3}$
}

Key Words: adaptive capacity; governance; ICDP; institutions; integrated conservation and development; land-use planning; local knowledge; participatory modeling; participatory research; resilience perspective

\section{INTRODUCTION}

In the early 1980 s, the protectionist paradigm that had dominated conservation began losing ground. It was replaced by a notion, in the developing world especially, that poverty reduction and environmental protection should be tackled in an integrated manner (Adams 1990). Several approaches emerged, building on early attempts that can be traced back to the 1960s (Garnett et al. 2007). The promotion of commercial nontimber forest product (NTFP) production is one of those approaches (Kusters et al. 2006). At the landscape level, integrated conservation and development projects (ICDPs) gained favor.

Integrated approaches appear to be at a crossroad (Adams et al. 2004, Sayer and Campbell 2004, Agrawal and Redford 2006). There are landscapes with vast natural assets where the local people remain deep in poverty (Fisher and Christopher 2007). This is well illustrated by the Malinau District in Kalimantan, Indonesia, which forms the focus of a number of studies in this Special Issue. Malinau District, which has significant biodiversity, timber, and mineral resources, has 56,000 people in an area larger than the Netherlands and yet a majority of the population experience poverty. Surely, the natural assets could form the basis for poverty alleviation without negatively affecting conservation values? Although there are many failures with integrated approaches, there are also some moderate successes, as is illustrated by the case study from Peru (Kilbane Gockel and Gray 2009). Therefore, in this special issue we have assembled a collection of studies that explore the options that might lead to at least a moderate level of development success in Malinau.

In this introductory essay, we synthesize some lessons from integrated conservation-development initiatives in developing countries, drawing particularly on the case study material in this special issue. There is an emerging consensus that at the heart of achieving positive outcomes are a core of institutional issues involving landscape governance, trust building, empowerment, and good communication, all implying long-term commitment by, and flexibility of, external actors. Fundamental to success is the recognition of the significant tradeoffs that occur between conservation and development goals. A variety of tools can be used to tackle the institutional issues and to confront the trade-offs. We close by reflecting on the resilience perspective to natural resource management, and what it has to offer integrated conservation and development initiatives in developing countries.

\section{MALINAU - THE CASE STUDY}

Malinau District, covering 42,000 $\mathrm{km}^{2}$, is a region of extreme change, especially since the collapse of the New Order (Boedhihartono et al. 2007). It is still largely covered in rainforest, with significant biodiversity (Sandker et al. 2007). The total population is small and sectors of the population remain poor (Levang et al. 2007), but some villages, for example, Setulang, are relatively better off (Wunder et al. 2008). 
The Centre for International Forestry Research (CIFOR) has been involved in research in the district for a decade, covering a wide spectrum of issues, from reduced-impact logging to landscape-level planning. Both government and conservation organizations have subscribed to the rhetoric of pursuing development pathways that would also conserve the rich biodiversity of the area (Boedhihartono et al. 2007). The work has been pursued during a period of weak governance, marked by corruption, political collusion, and nepotism. The timber resources of Malinau bring wealth to the district, though only a tiny portion reaches villagers. Massive oil palm schemes have been discussed but not yet established and at least to some extent this appears to be a cover for intensified timber extraction (Sandker et al. 2007).

\section{ACKNOWLEDGING AND DEALING WITH TRADE-OFFS}

In a review of the application of best practice principles in 15 ICDPs in the Lower Mekong region, Hill (2007) concluded that the principle that was least applied by conservation agencies was the need to acknowledge the occurrence of trade-offs. In the South African case study, the lack of acknowledgement of trade-offs was cited as one of the reasons for limited success (Dahlberg and Burlando 2009).

We have to acknowledge the difficulty of recognizing trade-offs. What constitutes a trade-off for one stakeholder may not be for another. In addition, although one element of development may be positive, other elements may not. For example, Kusters et al. (2006), using 55 cases of NTFP trade from Asia, Africa, and Latin America, show that there were situations in which some elements of livelihoods improved although inequality between households grew. In Malinau, members of one village saw the benefits of forest conservation whereas neighboring villagers were displeased with the conservation efforts (Wunder et al. 2008). Differences in conservation and development values are manifest at different scales. For example, local villagers in Setulang village in Malinau wanted one outcome whereas district-level officials wanted another (Wollenberg et al. 2007).

The Punan Tubu, a group of hunter-gatherers in East-Kalimantan, Indonesia, illustrate the very real trade-offs that are faced between conservation and development goals (Levang et al. 2007). The Punan clearly want conservation and development. In the district capital, the Punan benefit from all of the positive effects of development. Child and infant mortality are very low, and illiteracy has been eradicated in the younger generation. On the negative side, the Punan complain that nothing is free in town. Especially the older generation resent the loss of Punan culture. Because of frustration and unemployment, young people become easy targets for alcoholism and drug addiction. The Punan do not want to choose between conservation and development, between forest life and city life. They want to benefit from the advantages of both. They want to enjoy free forest products but also benefit from the positive aspects of modernity, to go wild boar hunting in the morning and watch television in the evening. They want to enjoy city life in the middle of the forest. The same kind of contradiction leads to identity problems. They want to uphold the traditional life of hunter-gatherers, but at the same time they reject the marginalization that this entails and seek integration into the larger society. In short, they want integration without loss of identity. Thus, even in a single household, the trade-offs play out; there is an immense complexity of trade-offs at the landscape level among multiple actors.

Sandker et al. (2007) demonstrate major differences in perspectives among stakeholders. Whereas conservationists are opposed to plans for logging and conversion of pristine tropical forest to oil palm plantations, the government in Malinau is willing to declare the district a "conservation district", one of only a few in Indonesia, while at the same time supporting large-scale conversion. Large-scale development, i.e., plantations and other intensive land use systems, will yield significant benefits to local authorities and to the local economy. However, there will undoubtedly be losers with such development, e.g., the Punan who rely on NTFPs, those displaced by plantation expansion, and conservationists.

Kusters et al. (2006) conclude that, even though NTFP production systems may provide environmental functions in agricultural landscapes, commercial NTFP production is not likely to reconcile development objectives with conservation of natural forests. More of one tends to mean less of the other. Efforts to achieve NTFP-based development only succeed in establishing conditions where people can intensify forest product management and production and improve their 
market access. However, these same conditions tend to have negative effects on natural forests. Conservation and development organizations need to understand these trade-offs.

Dahlberg and Burlando (2009) argue that the true cost of conservation must be recognized, and those bearing the opportunity costs must be rewarded. Payments for environmental services (PES) are regarded as one of the most exciting innovations in the conservation arena (Ferraro and Kiss 2002, Wunder 2007). They are seen as a more direct conservation approach than the indirect ICDP approach. However, it is apparent that the global biodiversity community is not yet ready to pay the costs. This is illustrated in Setulang village in Malinau. The villagers showed much initiative in preventing logging to save their forests and were interested in the possibility of PES (Wunder et al. 2008). However, buyers of biodiversity could not to be found. There was a reluctance of potential biodiversity donors to enter into a contingent, business-like arrangement in which they have to withdraw if the environmental services are not provided, or conversely, they have to keep paying for a long time if the system works well. This does not fit with the usual donor policy of two- to fouryear projects.

In defense of the potential buyers, there were numerous pitfalls to be dealt with, not least being the transaction costs of securing large land areas covering numerous villages; property rights issues resulting in inter-village conflicts; government policies that favor logging rather than PES; and unclear jurisdictions among local, district, and national levels. PES is a promising innovation but it may not be simple to implement in many landscapes. Attempting to fix some of the problems often brings one back to what needs to be the key focus of ICDPs: enabling collective action; empowering producer groups, who are the environmental service providers; clarifying rights and responsibilities; and facilitating decentralized management structures.

\section{THE INSTITUTIONAL CONTEXT OF CONSERVATION AND DEVELOPMENT}

In the South African case study, it was argued that a key failing was the top-down nature of decision making, rather than fairly negotiated trade-offs. This led to mistrust and resistance (Dahlberg and
Burlando 2009). The authors point to the need to recognize the unequal power relations, deal with unrealistic expectations, build trust, ensure transparency, and improve communications. These requirements need time and practitioners skilled in community development. Thus, there have to be realistic resource allocations to address these complex landscape issues, and development of the skills and competencies of the staff of conservation agencies has to be a priority. The Peruvian case makes similar points, stressing the following requirements for success: long-term commitment of external agencies, high levels of social capital, and building a sense of legitimacy in the local community organizations that includes respecting local knowledge (Kilbane Gockel and Gray 2009).

Given this background, the difficulties of facilitating positive outcomes in Malinau can be recognized. There are high degrees of centralization at the district level, top-down planning, governance weaknesses, and very limited attention to empowerment, to the point where officials distrusted the efforts of researchers to empower communities (Wollenberg et al. 2007). Garnett et al. (2007) also make the point that ICDPs are likely to be more effective when good governance is practiced, when attention is given to human capacity building, and when rights and responsibilities over land are clear.

\section{TOOLS AND APPROACHES FOR FACILITATING CONSERVATION AND DEVELOPMENT OUTCOMES}

Spatial planning is a crucial component of government land allocation and ICDP implementation. However, many spatial plans end up on shelves, unconnected to local realities and playing no role in guiding development, especially in regions where governance is weak. Wollenberg et al. (2008) propose five principles to support more interactive planning between land users and government. Their approach sees planning as essentially a process for tackling the institutional issues rather than being a mere source of maps.

1. Link local knowledge, experience, and the aspirations of different groups to formal land-use planning and decision making. The importance and necessity of including community perspectives in 
natural resource management has encouraged the development of a range of approaches and methodologies (Lynam et al. 2007). The necessity and difficulty of incorporating local perspectives is greatest in tropical forest-dependent communities where poverty, literacy, language, culture, and access can all pose obstacles to effective local engagement.

2. Develop the adaptive capacities of leaders and institutions through better communication and involvement of local land users and managers. Developing the adaptive capacities of different groups who have to work together is a key need in ICDPs. After several years of action research in Malinau to try to accomplish this, it became evident that the sociopolitical situation, leadership, and institutions changed so rapidly that efforts to develop collaboration were a moving and unreachable target. In the complex landscape of Malinau during this period of political reforms, numerous driving forces, stakeholders, and scales created an ever shifting institutional landscape. Leaders' needs for information and relative priorities for conservation and development changed in unpredictable ways. Because standard approaches to developing shared learning among diverse stakeholders did not work in this context, the facilitating team developed new principles for engaging with stakeholders. These required facilitation that was not planned and linear, but was rapidly adaptive and consistent with the principles of "muddling through" (Wollenberg et al. 2007). For example, it was necessary to maintain a near constant physical presence and maintain good relationships with the people closest to the leaders. This required a willingness to accept a significant investment of time and resources in relationship building.

3. Use systems frameworks for understanding land use as a process and anticipating change. One option here is participatory modelling (Sandker et al. 2007). Although this is focused on understanding the system, it also involves multistakeholder processes which help to empower different stakeholder groups with tools and concepts so that they can drive change themselves.

4. Work at multiple jurisdictional levels. This ensures that the driving forces of landscape change are taken into account; these forces are often actors that are well beyond the district level and who may render local plans meaningless. It means intervening at all levels from the local community to the national government and even influencing some international agencies and companies that are active in the landscape.

5. Build capabilities through explicit activities and procedures. It is usually insufficient to deliver new knowledge and options. The work needs to incorporate the key actors as they will be the ultimate users of any new knowledge or information.

This kind of interactive planning requires significant investments of time and goodwill. It is only appropriate in places of high resource value and threat, where the stakes are high. This approach complements rather than replaces, conventional spatial planning. What is added is a broader understanding of landscape scale processes and an exploration of a broader range of options that explicitly address difficult local and higher level governance issues. External facilitation is important, and probably essential, to ensure that power differentials do not distort the process and to help planners and managers to deal with the necessary transactions costs associated with broad participation and knowledge management.

\section{USING A RESILIENCE PERSPECTIVE}

New approaches and concepts are available to practitioners involved in conservation and development initiatives. Perhaps most important is the heightened realization that poverty reduction and biodiversity conservation may not, and in many 
cases will not, go hand in hand. Furthermore, there is heightened realization that institutional problems are at the core of constant failures in attempting integrated approaches.

What does resilience thinking have to offer conservation and development practitioners? Walker et al. (2004) define resilience as "the capacity to absorb disturbance and reorganize while undergoing change so as to still retain essentially the same function, structure, identity, and feedbacks". In the case of Malinau, there is much to be said for maintaining the resilience of the ecological system, with its high biodiversity. However, this is not so for the social system, which is characterized by poverty and weak governance. Given the entrenched political and economic interests geared toward maximizing short-term economic benefits and maintaining deeply disparate power relations among local actors, the social system focus in places such as Malinau should be on transformation, rather than resilience, though resilience may be an appropriate ideal for the indigenous cultures of the region. As Walker et al. (2010) argue, the question facing policy makers will increasingly become: "Which parts of our (locality, region or country), or which components or sectors, need enhanced resilience (in order to ensure their present, preferred states can continue), and which parts need to be transformed?"

Perhaps our attention should be more focused on resilience thinking than on the resilience of the system. As D. Armitage (personal communication) notes, "resilience thinking helps to direct learning around key variables that enable linked socialecological systems to renew and reorganize along sustainable trajectories in the face of perturbation." The approach's explicit recognition that science and policy must accept the constancy of change, the confusing nature of interactions across spatial and temporal scales, the limits to our ability to control nonlinear systems, and "the complexity inherent in articulating desirable pathways of change in the face of competing social interests" (D. Armitage, personal communication) speaks to our experiences in environments such as Malinau.
Responses to this article can be read online at: http://www.ecologyandsociety.org/vol15/iss2/art16/ responses/

\section{Acknowledgments:}

Most of the operational costs of the research presented in this Special Issue on Malinau were funded by the International Tropical Timber Organization. EU and IFAD funded the time of several CIFOR scientists participating in this special issue. We thank Steve Rhee for work on the resilience section of this essay.

\section{LITERATURE CITED}

Adams, W. M. 1990. Green development: environment and sustainability in the Third World. Routledge, London, UK.

Adams, W. M., R. Aveling, D. Brockington, B. Dickson, J. Elliot, J. Hutton, D. Roe, B. Vira, and W. Woolmer. 2004. Biodiversity conservation and the eradication of poverty. Science 306:1146-1149.

Agrawal, A., and K. Redford. 2006. Poverty, development and biodiversity conservation: shooting in the dark? Wildlife Conservation Society Working Paper Number 26. New York, New York, USA.

Boedhihartono, A. K., P. Gunarso, P. Levang, and J. Sayer. 2007. The principles of conservation and development: Do they apply in Malinau? Ecology and Society 12(2): 2. [online] URL: http://www.eco logyandsociety.org/vol12/iss2/art2/.

Dahlberg, A. C., and C. Burlando. 2009. Addressing trade-offs: experiences from conservation and development initiatives in the Mkuze wetlands, South Africa. Ecology and Society 14(2): 37. [online] URL: http://www.ecologyandsociety.org/voll4/ iss $2 / \operatorname{art} 37 /$.

Ferraro, P. J., and A. Kiss. 2002. Direct payments to conserve biodiversity. Science 298:1718-1719.

Fisher, B., and T. Christopher. 2007. Poverty and biodiversity: measuring the overlap of human 
poverty and the biodiversity hotspots. Ecological Economics 62:93-101.

Garnett, S. T., J. Sayer, and J. Du Toit. 2007. Improving the effectiveness of interventions to balance conservation and development: a conceptual framework. Ecology and Society 12(1): 2. [online] URL: http://www.ecologyandsociety.org/ vol12/iss 1/art2/.

Hill, E. 2007. Design of integrated conservation and development projects in the lower Mekong. Thesis, Charles Darwin University, Australia.

Kilbane Gockel, C., and L. C. Gray. 2009. Integrating conservation and development in the Peruvian Amazon. Ecology and Society 14(2): 11. [online] URL: http://www.ecologyandsociety.org/voll4/ iss2/art11/.

Kusters, K., R. Achdiawan, B. Belcher, and M. Ruiz Pérez. 2006. Balancing development and conservation? An assessment of livelihood and environmental outcomes of nontimber forest product trade in Asia, Africa, and Latin America. Ecology and Society 11(2): 20. [online] URL: http: //www.ecologyandsociety.org/vol11/iss2/art20/.

Levang, P., S. Sitorus, and E. Dounias. 2007. City life in the midst of the forest: a Punan huntergatherer's vision of conservation and development. Ecology and Society 12(1): 18. [online] URL: http: //www.ecologyandsociety.org/vol12/iss1/art18/.

Lynam, T., W. De Jong, D. Sheil, T. Kusumanto, and K. Evans. 2007. A review of tools for incorporating community knowledge, preferences, and values into decision making in natural resources management. Ecology and Society 12(1): 5. [online] URL: http://www.ecologyandsociety.org/vol12/iss1/ art5/.

Sandker, M., A. Suwarno, and B. M. Campbell. 2007. Will forests remain in the face of oil palm expansion? Simulating change in Malinau, Indonesia. Ecology and Society 12(2): 37. [online] URL: http://www.ecologyandsociety.org/vol12/iss2/ $\underline{\operatorname{art} 37 /}$.

Sayer, J., and B. M. Campbell. 2004. The science of sustainable development: local livelihoods and the global environment. Cambridge University Press, Cambridge, UK.
Walker, B. H., C. S. Holling, S. C. Carpenter, and A. P. Kinzig. 2004. Resilience, adaptability and transformability. Ecology and Society 9(2): 5. [online] http://www.ecologyandsociety.org/vol9/iss2/ art5.

Walker, B., J. Sayer, N. L. Andrew, and B. Campbell. 2010. Enhanced resilience as an objective of natural resource management in developing countries. Crop Science, in press.

Wollenberg, E., B. Campbell, E. Dounias, P. Gunarso, M. Moeliono, and D. Sheil. 2008. Interactive land-use planning in Indonesian rainforest landscapes: reconnecting plans to practice. Ecology and Society 14(1): 35. [online] URL: http: //www.ecologyandsociety.org/vol14/iss1/art35/.

Wollenberg, E., R. Iwan, G. Limberg, M. Moeliono, S. Rhee, and M. Sudana. 2007. Facilitating cooperation during times of chaos: spontaneous orders and muddling through in Malinau District, Indonesia. Ecology and Society 12(1): 3. [online] URL: http://www.ecologyandsoc iety.org/vol12/iss1/art3/.

Wunder, S. 2007. The efficiency of payments for environmental services in tropical conservation. Conservation Biology 21:48-58.

Wunder, S., B. Campbell, P. G. H. Frost, J. A. Sayer, R. Iwan, and L. Wollenberg. 2008. When donors get cold feet: the community conservation concession in Setulang (Kalimantan, Indonesia) that never happened. Ecology and Society 13(1): 12. [online] URL: http://www.ecologyandsociety.org/vol13/ iss1/art12/. 